\title{
Estimation of Forest Area and its Dynamics in Russia Based on Synthesis of Remote Sensing Products
}

\author{
D.G. Schepaschenko ${ }^{1,2}$, A.Z. Shvidenko ${ }^{1,3}$, M.Y. Lesiv ${ }^{1,4}$, P.V. Ontikov ${ }^{2}$, \\ M.V. Shchepashchenko ${ }^{5}$, F. Kraxner ${ }^{1}$ \\ ${ }^{1}$ International Institute for Applied Systems Analysis, Schlossplatz 1, A-2361, Laxenburg, Austria \\ ${ }^{2}$ Moscow State Forest University, Institutskaya 1, Mytischi, Moscow reg., 141005, Russian \\ Federation \\ ${ }^{3}$ Sukachev Institute of Forest, Siberian Branch, Russian Academy of Sciences, Akademgorodok \\ 50/28, Krasnoyarsk, 660036, Russian Federation \\ ${ }^{4}$ Lviv Polytechnic National University, Bandera street 12, Lviv, 79013, Ukraine \\ ${ }^{5}$ Russian Institute of Continuous Education in Forestry, Institutskaya 17, Pushkino, Moscow reg., \\ 141200, Russian Federation \\ e-mail: schepd@gmail.com
}

\begin{abstract}
We review up-to-date, open access remote sensing (RS) products related to forest. We created a hybrid forest/non-forest map using geographically weighted regression (GWR) based on a number of recent RS products and crowdsourcing. The hybrid map has spatial resolution of $230 \mathrm{~m}$ and shows the extent of forest in Russia in 2010. We estimate area of Russian forest as 711.3 million ha (in accordance with Russian national forest definition). Compared to official data of the State Forest Register (SFR), RS estimates the area of forest to be considerably larger in European part (+12.2 million ha or $+8 \%)$ and smaller in Asian (-39.8 million ha or $-7 \%)$ part of Russia. We report the changing forest area in 2001-2010 and discuss main drivers: wildfire and encroachment of abandoned arable land. The methodology used here can by applied for monitoring of forest cover and enhancing the forest accounting system in Russia.
\end{abstract}

Key words: Russian forest, remote sensing, crowdsourcing, forest cover, geographically weighted regression

DOI: $10.1134 / S 1995425515070136$

Knowledge of the state and dynamics of forest cover is essential for consistent forest policy and is a prerequisite for the transition to sustainable forest management. According to official data, about half of Russian forests were inventoried more than 25 years ago (Solontsov, 2010). In reality, the situation is even more pessimistic, since large areas were estimated using approximate methods. In addition, a number of drivers have caused significant changes in forest cover in recent decades. For example, climate change and the deterioration of the wildfire protection have contributed to an increase in the number of fires and the area affected (Shvidenko et al., 2011; Shvidenko, Schepaschenko 2013). Forested area affected by fires is estimated at an average of 5.0-5.5 million ha every year over the last decade. Furthermore, this results in tree mortality in the first three postfire years covering an area of more than 2 million ha annually (Aerospace ..., 2009; Bartalev, 2007, 2015; Vivchar et al., 2010; Lavrov, Loupian, 2013; Krylov et al., 2014). Other disturbances (logging, insect outbreaks and disease) also have a tendency to increase.

The need for up-to-date information about state and dynamics of forest cover is evident. However, current forest monitoring and inventory are not satisfactory; assessments of forest cover do not cover the entire country on a certain date, for instance, and it is clear that this task can be solved only by involving RS.

A number of global and regional forest maps, encompassing Russian territory, have been published in recent years. They are based on the various RS tools in combination with (usually very limited) ground-based measurements. Forest definitions are often not consistent across datasets and when compared, the maps often contradict each other. Furthermore, they all deviate from SFR data. 
In this paper, we have demonstrated the ability to create a new hybrid forest cover map based on existing RS products and GIS technology to extract the maximum information from existing maps. The new hybrid forest map is more accurate than any of input maps and corresponds to the national definition of forest.

\section{MATERIALS AND METHODS}

Twelve different global RS datasets were analyzed and used to produce a hybrid forest cover map for Russia. Input datasets came from different sources (European, American, Chinese and Japanese Space Agencies) and satellite instruments (multi-spectral, radar), and have different spatial resolution (from $30 \mathrm{~m}$ to $1 \mathrm{~km}$ ). They included:

Global Land Cover - GLC2000 (Bartalev et al., 2003), which uses 2000 as a reference year and has spatial resolution of $1 \mathrm{~km}$. The dataset was based on the instrument VEGETATION of the satellite SPOT 4. Local experts were involved in interpretation of the imagery. GLC-2000 has six pure forest classes and two mosaics which include forest. Despite the significant "age", this is one of the most validated RS products.

GlobCover has a resolution of 300 m (Defourny et al., 2006). It was produced by the initiative of the European Space Agency and based on ENVISAT-MERIS. The reference years are 2005 and 2009. GlobCover legend consists of 22 classes in total, eight of which are pure forest and five which are mosaics including forest.

Land cover GlobLand30 (Jun et al., 2014) is based on multispectral images of the US satellite Landsat and the Chinese satellite HJ-1. The product has a resolution of $30 \mathrm{~m}$ for the reference year of 2010. The legend contains of 10 classes, with only one dedicated to forest, including dense and sparse forests with a canopy cover equal or over $10 \%$.

MCD12Q1 was established based on the MODIS instrument from Terra and Aqua satellites. The datasets are available on the website of the US Geological Survey (https://lpdaac.usgs.gov/data_access) for each year from 2001 to 2012. They have a spatial resolution of $463 \mathrm{~m}$. We used maps for 2001 and 2010 with the IGBP classification (Friedl et al., 2010), which has six forest classes out of a total of 17.

Tree cover map MODIS VCF (DiMiceli et al., 2011) is based on the MODIS/Terra and is also available on the website of the US Geological Survey, in this case for the period 2000-2010. Tree cover percentage is specified for each pixel with a resolution of $231 \mathrm{~m}$.

Forests map by the FAO (FAO, 2012) is the global percentage tree cover in 2010, with a spatial resolution of $250 \mathrm{~m}$. It is freely available at http://www.fao.org/forestry/fra/80298/en/. The dataset is based on MODIS VCF (Hansen et al., 2003), maps of climatic zones, topography and water bodies.

GLC-SHARE is another FAO dataset, launched in 2014 (Latham et al., 2014) and available at http://www.glcn.org/databases/lc_glcshare_en.jsp. This hybrid product is a mosaic of several regional maps, and according to the FAO it is the most accurate in relation to ground data. This dataset consists of several layers, including a major land cover forest class with tree cover over $10 \%$ ) and another layer - the percentage of tree cover. The spatial resolution of the dataset is $1 \mathrm{~km}$.

European Space Agency and Climate Change Initiative launched three global land cover maps (ESA/CCI) for the years 2000, 2005 and 2010. Each of these maps is based on the time series of satellite images MERIS and SPOT-Vegetation, collected over 5 years: 1998-2002, 2003-2007 and 2008-2012 respectively. Apparently, this averaging causes only marginal land cover changes between the epochs. The spatial resolution of the datasets is $300 \mathrm{~m}$, and the maps are available at http://www.esa-landcover-cci.org/?q=node/158.

Global forest change for the years 2000-2012 was analyzed by Hansen et al. (2013) based on Landsat imagery. The product contains a map of the tree cover in 2000, the annual loss of forest for the period 2001-2012 and forest gain map for the entire period. These maps have a resolution of 30 $\mathrm{m}$ and are available at http://earthenginepartners.appspot.com/science-2013-global-forest. 
Another dataset based on Landsat and MODIS VCF was published by Sexton et al. (2013), available at http://landcover.org/data/landsatTreecover/. They disaggregated MODIS VCF (231 m) to the resolution of $30 \mathrm{~m}$ using Landsat imagery. The dataset includes both 2000 and 2005 years and contains information about the closeness of the tree canopy.

A series of forest maps was built on the radar instrument ALOS PALSAR by Shimada et al., (2011) for 2007-2010. It has a resolution of $100 \mathrm{~m}$ and represents four classes of canopy closure (10-25\%, 26-50\%, 51-75\%, 76-100\%). The series is available on the website of the Japanese Space Agency (http://www.eorc.jaxa.jp/ALOS/en/palsar_fnf/fnf_index.htm).

Another radar-based dataset is GSV 2010, which uses Envisat ASAR by European Space Agency to represent the growing stock volume in $\mathrm{m}^{3} /$ ha (Santoro et al., 2014). It has a resolution of $1 \mathrm{~km}$ and the base year is 2010 .

All the datasets mentioned above were resampled to the target resolution of $230 \mathrm{~m}$ and values were converted into a probability of forest in a given pixel. Most of the datasets are dated 2010, the only significant deviation being GLC-2000, but the map is one of the most accurate for the country and allows reliable identification of stable (unaltered) forest areas.

We apply the method of geographically weighted regression (GWR) to integrate 12 different maps into one hybrid dataset. GWR is a statistical method (Brunsdon et al., 1998; See et al., 2014), which evaluates how well source maps correspond to the reference dataset. Thus, each map gets its "weight", and this weight varies spatially. Accordingly, it is possible to calculate the probability of forest at any particular point using the weighted information from all original maps. A probability threshold of 50\% was used to assign a pixel to forest. The reference dataset is a key for this method, and we created it by visual classifying of high-resolution images from Google Earth using tool GeoWiki (Fritz et al., 2012). We classified about 6,000 pixels of $230 \mathrm{~m}$ size, of which 5,300 were used to train the GWR model and 727 for the subsequent validation. Percentage forest cover was estimated in each pixel, and reference points were randomly distributed over the country, although the lack of high-resolution images for some remote regions limited the ability to classify points there (Fig. 1).



Fig. 1. Training (5300 pixels) and validation (727 pixels) datasets 
The validation dataset was selected from the reference dataset on a regular-random basis. The country was covered with a grid of 2x2 degrees, and in each grid cell, one point - the closest to the center - was selected for the validation.

\section{RESULTS AND DISCUSSION}

Total forest area were calculated for each of the 12 source maps and for hybrid map (Table 1). The area of forest class in the land cover maps (e.g. GLC2000, MCD12Q1) was fully summed up to the forest, while only $20 \%$ (conservatively) of the area of mosaic classes were accounted. Datasets representing tree cover percentage (e.g., MODIS VCF) were attributed to the forest with a threshold of $25 \%$, which corresponds to the definition of the Russian forest. In oder to compare RS and SFR data, we selected the SFR area of all tree species and half the area of dwarf pine, i.e. that part of the forest statistics which to the greatest extent meet the RS definition of "forest", amounting to 738.9 million ha. The rest SFR forest area are shrubs (58.1 million hectares), included in Russian statistics in forested land, but in most cases cannot be recognized from space as a forest.

Table 1. Area of Russian forest estimated by different sources, million hectares

\begin{tabular}{|c|c|c|c|c|}
\hline \multirow{2}{*}{ Dataset } & \multirow[t]{2}{*}{$\begin{array}{l}\text { Apparent } \\
\text { error, \% }\end{array}$} & \multicolumn{3}{|c|}{$\begin{array}{l}\underline{\text { Forest area }} \\
\text { Forest area change 2000-2010 }\end{array}$} \\
\hline & & Russia & European part & Asian part \\
\hline State Forest Register, $2010^{1}$ & & $\frac{738.9}{+19.8}$ & $\frac{153.3}{+0.9}$ & $\frac{585.6}{+18.9}$ \\
\hline GLC2000 ${ }^{2}$ & 10 & 847.5 & 178.1 & 669.4 \\
\hline GlobCover & 16 & 872.0 & 175.4 & 696.6 \\
\hline GlobLand $30^{3}$ & 10 & 778.4 & 146.6 & 631.8 \\
\hline Modis MCD12Q1 & 11 & $\frac{675.8}{+31.5}$ & $\frac{176.5}{+18.2}$ & $\frac{499.3}{+13.4}$ \\
\hline Modis VCF & 13 & $\frac{571.5}{-39.3}$ & $\frac{162.0}{-10.6}$ & $\frac{409.4}{-28.8}$ \\
\hline $\begin{array}{l}\text { FAO forest } \\
\text { FAO GLC-Share }{ }^{3}\end{array}$ & $\begin{array}{l}17 \\
15\end{array}$ & $\begin{array}{l}761.2 \\
910.4\end{array}$ & $\begin{array}{l}185.8 \\
192.8\end{array}$ & $\begin{array}{l}575.3 \\
717.6\end{array}$ \\
\hline ESA/CCI & 11 & $\frac{895.6}{-1.3}$ & $\frac{174.4}{-0.1}$ & $\frac{721.2}{-1.2}$ \\
\hline Hansen et al., 2013 & 6 & $\frac{754.1}{-24.5}$ & $\frac{172.2}{-4.5}$ & $\frac{581.9}{-20.0}$ \\
\hline Sexton et al., 2013 & 12 & 556.4 & 160.6 & 395.8 \\
\hline $\begin{array}{l}\text { JAXA Palsar } \\
\text { GSV } 2010\end{array}$ & $\begin{array}{l}11 \\
17\end{array}$ & $\begin{array}{l}726.6 \\
781.7\end{array}$ & $\begin{array}{l}160.3 \\
203.3\end{array}$ & $\begin{array}{l}566.3 \\
578.4\end{array}$ \\
\hline Hybrid dataset & 4 & 711.3 & 165.5 & 545.9 \\
\hline
\end{tabular}

${ }^{1}$ forested area, including all tree species and half area of dwarf pine

${ }^{2}$ forest classes $-100 \%$ of area, mosaic classes with share of forest $-20 \%$ of area

${ }^{3}$ dense and sparse forest with tree cover density $10 \%$ or higher

Table 1 shows the significant range in estimates of forest area, which can be explained partly by differences in the forest definition and the coarse resolution of some RS products. Another source of discrepancy is the use of different indicators of tree cover (canopy cover, the area of projection of crowns) in different datasets and the adoption of uniform thresholds for all tree species, even though the relationship between the tree cover and stand's stocking may differ substantially for different tree species and under different site conditions (Sukhikh, 2005). There are 
huge differences (more than 100 million hectares) in the assessment of forest area in the two products obtained from the same sensor - MODIS VCF and MODIS MCD12Q1, when the tree cover threshold of $25 \%$ for the MODIS VCF is adopted. However, using a threshold of $20 \%$ for the entire country gives similar area estimations for both products. Considering the European and Asian areas of the country separately, we found that thresholds $24 \%$ and $14 \%$ respectively would give forest area estimates similar to those of the SFR in each region. The need for a low threshold for the Asian part of the country can be explained by the fact that larch, with its sparse deciduous crown, is the dominant tree. However, the opposite direction of the forest change 2000-2010 in these two products is difficult to explain.

The hybrid forest/non-forest map of Russia is shown in Fig. 2. The total forest area in Russia (Russian national forest definition, without shrubs indicated as forest by Russian inventory rules) in 2010 is estimated at 711.3 million hectares or 27.6 million hectares less $(-4 \%)$ than the SFR data. In the European part of the hybrid map forest area estimates are higher $(+12.2$ million hectares or $+8 \%$ ) compared to the SFR. However, in the Asian areas estimates are substantially lower: -39.8 million ha (-7\%) compared to the SFR. Higher estimates in the European part can be explained mainly by the natural afforestation of abandoned agricultural land as well as the inclusion of sparse northern forests outside the forest fund (area with forest management plan). The amount of natural afforestation on abandoned land can only be estimated approximately. Using the official statistics of abandoned arable land for the period of 1990-2010 (31.6 million hectares), and assuming a similar share of abandoned pastures, hayfields and fallows (Osnovnye ... 2012), the total area of abandoned agricultural land was 56.8 million hectares. To estimate the proportion of abandoned area that underwent afforestation we used long-term average data on natural regeneration of non-forested lands specific to the bioclimatic zones (Prognoz ..., 1991) reduced by 25\% (to be conservative). Afforested area was estimated as 18 million hectares, of which two thirds are in the European part of Russia. This is a conservative estimate; however, for the European part of Russia it is almost identical to our own estimate-from the hybrid map-of forest area in 2010.

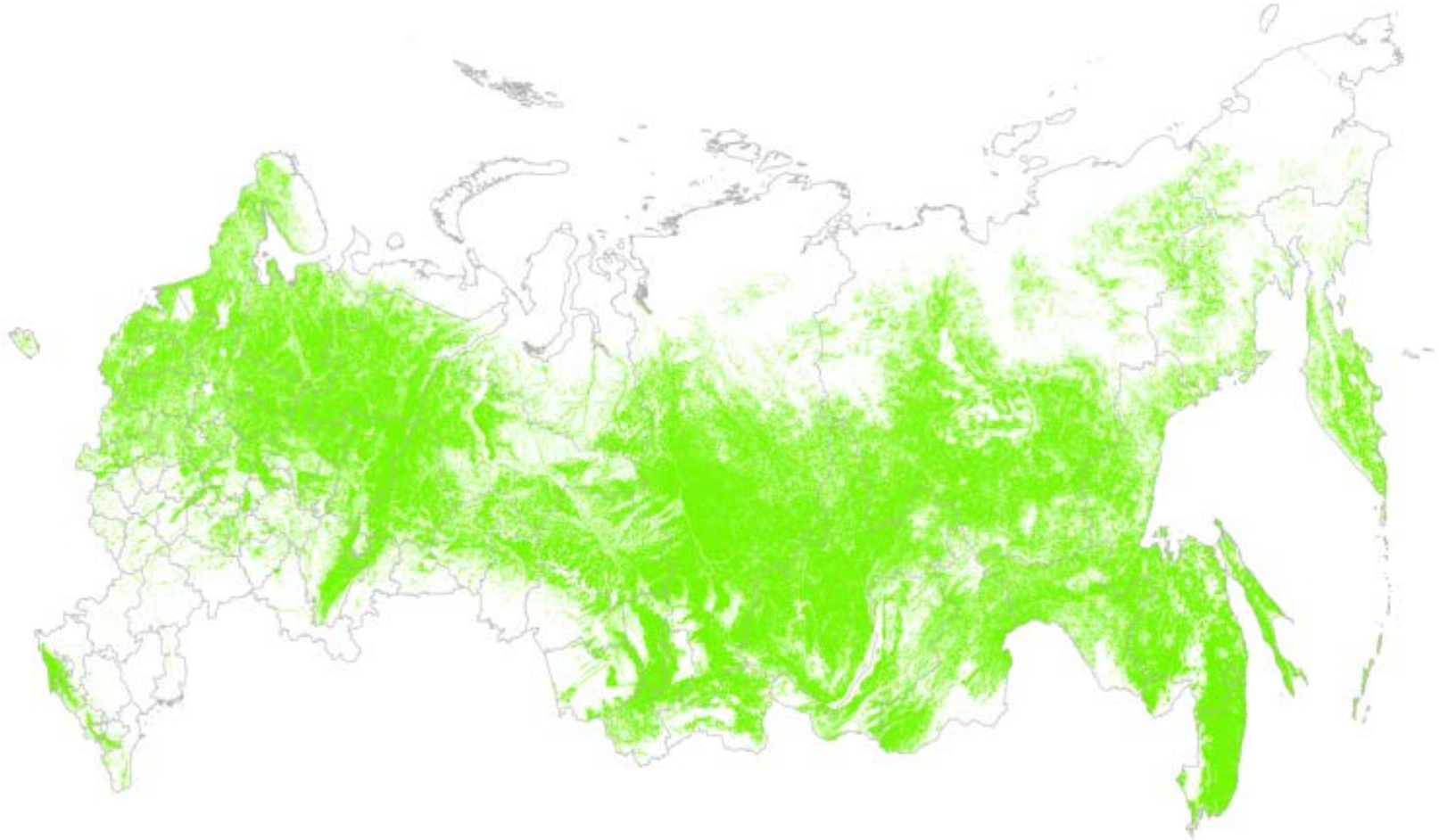

Fig. 2. Hybrid forest/non-forest map of Russian forests is available for browsing and download in full resolution (230 m) at: http://Russia.geo-wiki.org

The lower estimates of forest area in the Asian area is very likely due to natural and anthropogenic disturbances, mainly wildfire, biogenic (insects/diseases) factors and industrial development. About 2.5 million hectares of forest a year have been lost to wildfires over the past 
two decades (Shvidenko et al., 2011). Several extensive outbreaks of Siberian moth have been recorded, the largest of which covered an area of about 10 million hectares in 2000-2001. Although these outbreaks occurred mainly in larch forests, which do not usually die after a single defoliation. Other forest losses due to insect outbreaks, intense oil and gas extraction, and dieback of coniferous forests are not officially recorded in the statistics. Comparison of the hybrid forest map with the SFR leads to the conclusion that Russia has lost about 45 million hectares over the past 10-15 years in territories managed by the state forest authorities. This does not take into account natural afforestation on abandoned agricultural land, which is not accounted for in the SFR, and excludes shrubland, which is included in the SFR.

The hybrid forest map and the validation dataset matched in $96 \%$ cases, demonstrating that the hybrid forest map had the lowest error (4\%) compared with any of the initial maps (Tab. 1). Errors can be partially explained by the lack of up-to-date, high-resolution imagery for some areas in Siberia. Most of the imagery used for validation refer to the period 2008-2012, while the majority of misclassified images are for the year 2005. Some disturbances may have occurred between the year of RS observation (2005) and the target year (2010). This hypothesis is supported by the fact that 22 out of 29 "false" points were classified as "forest" in 2005 (Google Earth), but the model (based on other RS datasets) projects no forest in those locations in 2010. In any case, the effect of these errors on the final estimate is marginal.

One of the most ambitious recent projects to assess the dynamics of the forest globally (Hansen et al., 2013), estimates that Russia lost 24.5 million hectares of forest between 2000 and 2010 (Table. 1). This dataset had lowest error (6\%) after our hybrid dataset. All other datasets had an error within the range of $10-17 \%$.

Forest losses are most evident for the Northern and Trans-Baikal regions and the greatest discrepancy between RS and the SFR is in the Sakha Republic (Table 2). Although these are differences among the estimates, all of the most accurate RS products report much smaller forest area than indicated in the SFR. The highest discrepancy are between estimates produced by MODIS VCF and the SFR data was -88.7 million hectares. This difference can be explained partly by nature of larch forest (light, sparse, deciduous crown) and by the instrument (accounted canopy cover, which recognizes not only the gaps between the crowns projection, but also gaps within the crown). Therefore, the universal threshold of 25\% canopy cover is too high for the larch forests, which make up about 75\% of the forests of the Republic of Sakha. Our GWR model uses a geographically variable threshold to approximate the training dataset. As a result, the hybrid dataset estimates forest area in the Sakha Republic to be 107.9 million hectares (the deviation from SFR is -31.0 million hectares). This is close to the estimates of the high-resolution products - Hansen et al. (2013), Sexton et al. (2013), JAXA Palsar (102-118 million hectares, with the SFR deviation from 30.2 to -36.4 million hectares). Northern sparse and low productive (V-Vb site indexes) larch forest typically can be classified as forest by the Russian definition starting with $11 \%$ tree cover. Incidentally, application of this threshold with MODIS VCF produces an estimate of the forest area of the Sakha Republic, which almost identical to that of the hybrid map.

Note that using the same variable, tree-specific thresholds for Modis VCF in 2000 and 2010, gives a reduction in forest area of 39.3 million ha, including 10.6 million hectares in the European and 28.8 million hectares in the Asian area of Russia. Therefore there is no doubt that the area of Russian forests managed by forestry authorities has been reduced. Approximately 45 million hectares in the last 15-20 years has been lost, mainly from unmanaged forests at high latitudes. We point out a somewhat larger time interval than used in the analysis because the SFR data have considerable inertia time and part of the forest cover could have been lost during the second half of the 1990s. 
Table 2. Forest area in the Sakha Republic estimated by different sources, million hectares

\begin{tabular}{l|c|c|c|c}
\hline Dataset & $\begin{array}{c}\text { Apparent } \\
\text { error, } \\
\%\end{array}$ & $\begin{array}{c}\text { Forest area } \\
2010, \\
10^{6} \text { ha }\end{array}$ & $\begin{array}{c}\text { Difference } \\
\text { to SFR, } \\
10^{6} \text { ha }\end{array}$ & $\begin{array}{c}\text { Area change } \\
2000-2010, \\
10^{6} \text { ha }\end{array}$ \\
\hline State Forest Register (SFR) & 17 & 138.9 & 0 & +12.9 \\
GLC2000 & 26 & 167.3 & +28.4 & n.d. \\
GlobCover & 14 & 178.2 & +39.3 & n.d. \\
GlobLand30 1 & 18 & 95.8 & +18.6 & n.d. \\
Modis MCD12Q1 & 25 & 50.2 & -43.1 & +1.7 \\
Modis VCF (>25\%) & 19 & 109.7 & -29.2 & -16.9 \\
Modis VCF (>11\%) & 29 & 100.3 & -38.6 & -58.0 \\
FAO forest & 19 & 181.5 & +42.6 & n.d. \\
FAO GLC-Share 1 & 17 & 199.4 & +60.5 & n.d. \\
ESA/CCI & 10 & 118.0 & -20.9 & -5.7 \\
Hansen et al., 2013 & 26 & 102.5 & -36.4 & n.d. \\
Sexton et al., 2013 & 19 & 108.7 & -30.2 & n.d. \\
JAXA Palsar & 27 & 93.8 & -45.1 & n.d. \\
GSV 2010 & 5 & 107.9 & -31.0 & n.d. \\
Hybrid dataset & & &
\end{tabular}

${ }^{1}$ including sparse forest, tree cover density $10 \%$ or higher

\section{CONCLUSION}

We presented a hybrid forest/non-forest map of Russian forest with a resolution of $230 \mathrm{~m}$. To produce this map we used almost all freely available spatial datasets on Russian forest cover. The hybrid map is the most accurate compared to other RS products at the target resolution. Existing RS datasets give quite a wide range of estimations of Russian forest area. This fact can be partly explained by differences in forest definitions, the technical capabilities of satellite instruments and processing procedures. The global approach, for instance, cannot reflect some regional/trees species-specific characteristics.

A significant difference between the official forest inventory and our results were observed. The main reason for this is outdated information used by the SFR, which does not have a satisfactory updating procedure. Along with substantial area of naturally afforested abandoned agricultural land (mainly in the European part of the country), forest area managed by the forestry authorities, decreased by about 45 million hectares, mostly in remote unmanaged and unprotected forests. This estimation corresponds to evaluation of losses due to natural (mainly fires) or human induced (logging, industrial development, oil/gas extraction) together with significant reduction of reforestation.

Obviously, the urgently needed transition to sustainable forest management is impossible without reliable and timely information about forests. Creating an efficient and accurate forest accounting system will require considerable effort and time. Using our method to produce a new hybrid map every 2-3 years can contribute to a new forest accounting system, helping to close the knowledge gap regarding forest state and dynamics in Russia.

The hybrid map is available for browsing and download at http://forest.geo-wiki.org.

\section{ACKNOWLEDGMENTS}

This research was partly supported by European projects AGRICISTRADE (612755), Independent monitoring GHG (CLIMA.A.2/ETU/2014/0008), ZAPAS (263271), as well as NEFCA, funded by National Institute for Environmental Studies, Japan. We grateful to Daisy Brickhill from IIASA communications department for improving English. 


\section{References}

1. Aerokosmicheskii monitoring katastroficheskikh pozharov v lesakh Vostochnoi Sibiri (Aerospace monitoring of catastrophic fires in the forests of Eastern Siberia). Sukhinin A.I. Ed. Otchet po NIR. Krasnoyarsk: Institut lesa SO RAN, 2009. 91p.

2. Bartalev S.A. Development of methods for assessing the status and dynamics of forests on the satellite-based observations. Doctor's techn. sci. thesis), M: IKI RAN, 2007. 48 p.

3. Bartalev S.A., Belward A.S., Erchov D.V., Isaev A.S. A new SPOT4-VEGETATION derived land cover map of Northern Eurasia, International Journal of Remote Sensing, 2003, No 24, pp. 1977-1982. doi: 10.1080/0143116031000066297.

4. Bartalev S.A., Stytsenko F.V., Egorov V.A., Lupyan E.A. Satellite based assessment of post fire mortality of Russian forests), Lesovedenie, 2015, № 2, pp.83-94.

5. Brunsdon C., Fotheringham S., Charlton M. Geographically Weighted RegressionModelling Spatial Non-Stationarity, Journal of the Royal Statistical Society. Series D (The Statistician), 1998, Vol. 47(3), pp. 431-443. doi:10.2307/2988625

6. Defourny P., Vancustem C., Bicheron P., Brockmann C., Nino F., Schouten L., Leroy M. GLOBCOVER: A 300m global land cover product for 2005 using ENVISAT MERIS time series, Proceedings of the ISPRS Commission VII Mid-Term Symposium: Remote Sensing: from Pixels to Processes. 2006. Enscede NL. Available at: http://metaliba.lib.ucl.ac.uk/V?func=find-ej-1

7. DiMiceli C.M., Carroll M.L., Sohlberg R.A., Huang C., Hansen M.C., Townshend J.R.G. Annual Global Automated MODIS Vegetation Continuous Fields (MOD44B) at 250 m Spatial Resolution for Data Years Beginning Day 65, 2000-2010, Collection 5 Percent Tree Cover. University of Maryland, 2011. Available at: http://glcf.umd.edu/data/vcf/

8. Friedl M.A., Sulla-Menashe D., Tan B., Schneider A., Ramankutty N., Sibley A., Huang X. MODIS Collection 5 global land cover: Algorithm refinements and characterization of new datasets, Remote Sensing of Environment, 2010, Vol. 114(1), pp. 168-182. doi:10.1016/j.rse.2009.08.016

9. Fritz S., McCallum I., Schill C., Perger C., See L., Schepaschenko D., van der Velde M., Kraxner F., Obersteiner, M. Geo-Wiki: An online platform for improving global land cover, Environmental Modelling \& Software, 2012, Vol. 31, pp. 110-123. doi:10.1016/j.envsoft.2011.11.015

10. Jun C., Ban Y., Li S. China: Open access to Earth land-cover map, Nature. 2014. Vol. 514, p. 434. doi:10.1038/514434c.

11. Hansen M.C., Potapov P.V., Moore R., Hancher M., Turubanova S.A., Tyukavina A., Townshend J.R.G. High-Resolution Global Maps of 21st-Century Forest Cover Change, Science, 2013, No 342(6160), pp. 850-853. doi:10.1126/science.1244693

12. Krylov A., McCarty J.L., Potapov P., Loboda T., Tyukavina A., Turubanova S., Hansen M.C. Remote sensing estimates of stand-replacement fires in Russia, 2002-2011, Environmental Research Letters, 2014, No 9(10). Doi: 10.1088/17489326/9/10/1005007.

13. Latham J., Cumani R., Rosati I., Bloise M. Global Land Cover SHARE (GLC-SHARE) database. Beta-Release Version 1.0 - 2014. FAO, 2014, 40 p. Available at: http://www.glcn.org/downs/prj/glcshare/GLC_SHARE_beta_v1.0_2014.pdf

14. Laverov N.P., Lupyan E.A. Razrabotka metodov i tekhnologii otsenki ploshchadei, proidennykh lesnymi prirodnymi pozharami (Development of methods and technology for assessment area of forest fire), Konferentsiya, posvyashchennoi yubileyu akademika R.Z. Sagdeeva (Conference Dedicated to the 80 Anniversary of Academician R.Z. Sagdeeva). Kazan, 21.01.2013. http://www.forestforum.ru/viewtopic.php?f=9\&t=14001.

15. Osnovnye pokazateli sel'skogo khozyaistva $v$ Rossii (Key indicators of agriculture in Russia). Byulleten'. Federal'naya sluzhba gosudarstvennoi statistiki (Rosstat). 2012. 
Available

http://www.gks.ru/wps/wcm/connect/rosstat_main/rosstat/ru/statistics/publications/catal og/doc_1140096652250

16. Prognoz ispol'zovaniya i vosproizvodstva lesnykh resursov po ekonomicheskim raionam SSSR do 2010 goda (Forecast of use and reproduction of forest resources by economic regions of the USSR until 2010). Isaev A.S. Ed. Vol. 1. M., AN SSSR, 2000. 509 p.

17. Santoro M., Beaudoin A., Beer C., Cartus O., Fransson J.E.S., Hall R.J., Wegmüller U. Forest growing stock volume of the northern hemisphere: spatially explicit estimates for 2010 derived from Envisat ASAR data, Remote Sensing of Environment, 2015. No 168, pp.316-334.

18. See L., Schepaschenko D., Lesiv M., McCallum I., Fritz S., Comber A., Perger Ch., Schill Ch., Zhao Y., Maus V., Sirajh M.A., Albrecht F., Cipriani A., Vakolyuk M., Garcia A., Rabia A.H., Singha K., Marcarini A.A., Kattenborn T., Hazarika R., Schepaschenko M., van der Velde M., Kraxner F., Obersteiner M. Building a hybrid land cover map with crowdsourcing and geographically weighted regression, ISPRS Journal of Photogrammetry and Remote Sensing. 2015. V. 103, pp. 48-56. doi:10.1016/j.isprsjprs.2014.06.016.

19. Sexton, J.O., Song, X.-P., Feng, M., Noojipady, P., Anand, A., Huang, C., Kim, D.-H., Collins, K.M., Channan, S., DiMiceli, C., and Townshend, J.R., Global, 30-m resolution continuous fields of tree cover: Landsat-based rescaling of MODIS vegetation continuous fields with lidar-based estimates of error, Int. J. Digital Earth, 2013, vol. 6, no. 5, pp. 427-448. doi: 10.1080/17538947.2013.786146

20. Shimada, M., Isoguchi, O., Motooka, T., Shiraishi, T., Mukaida, A., Okumura, H., Otaki T., Itoh, T. Generation of $10 \mathrm{~m}$ resolution PALSAR and JERS-SAR mosaic and forest/non-forest maps for forest carbon, Geoscience and Remote Sensing Symposium (IGARSS), 2011, IEEE International, pp. 3510-3513. doi: 10.1109/IGARSS.2011.6049978.

21. Solontsov O.N. Napravleniya razvitiya gosudarstvennoi inventarizatsii lesov v Rossii (Development of the state forest inventory in Russia), Materials of the II International), Problemy lesoustroistva i gosudarstvennoi inventarizatsii lesov v Rossii (The Problems of Forest Management and State Forest Inventory in Russia). 8-10 dekabrya 2010 g., Vologda. Available at: http://www.roslesinforg.ru/press/news/35.

22. Sukhikh V.I. Aerokosmicheskie metody v lesnom khozyaistve i landshaftnom stroitel'stve (Aerospace methods in forestry and landscape construction). Ioshkar-Ola, Minnauki RF. 2005, 390 p.

23. Shvidenko A.Z., Shchepashchenko D.G., Vaganov E.A., Sukhinin A.I., Maksyutov Sh.Sh., MkKallum I., Lakida I.P. Impact of wildfires in Russia 1998-2010 on ecosystems and the global carbon budget, Doklady Earth Science, 2011, Vol. 441, No 2, pp. 1678-1682.

24. Shvidenko A.Z., Shchepashchenko D.G. Climate change and wildfires in Russia. Contemporary Problems of Ecology, 2013, Vol. 6, No. 7, pp. 683-692.

25. Vivchar A.V., Moiseenko K.B., Pankratova N.V. Estimates of carbon monoxide emissions from wildfires in northern Eurasia for airquality assessment and climate modeling. Izvestiya - Atmospheric and Ocean Physics, 2010. Vol. 46, No 3, pp. 281-293. 